\title{
Role of elected representatives of Panchayat Raj Institutions (PRIs) in enhancing rural health services in Tumkur district of Karnataka
}

\author{
N. KUMARA* AND NEHAL A. FAROOQUEE \\ Department of Extension and Development studies, Indira Gandhi National Open University, \\ NEW DELHI, INDIA \\ (Email : nkumar278@gmail.com)
}

\begin{abstract}
The introduction of the community development programme (CDP) in the first five year plan gave a new dimension as well as impetus to the participation of people in development. Development implies on overall positive change in the physical quality of life. This positive change for the better encompasses economic as well as social aspects. In other words Development implies growth with justice; it means an improvement in the quality of life through better Health, Education, Housing and Welfare. Study reveals that majority (70 \%) of the elected members of Panchayat Raj Institutions (PRIs) were having low / less knowledge about Rural health programmes and their role in enhancing rural health services to community. It is evident from study was majority $(46.66 \%)$, of the elected members educational level was middle school and High school level.
\end{abstract}

KeY WorDs : Health, Development, Community, Panchayat Raj

View Point Article : Kumara, N. and Farooquee, Nehal A. (2014). Role of elected representatives of Panchayat Raj Institutions (PRIs) in enhancing rural health services in Tumkur district Karnataka state India . Internat. J. Home. Sci. Extn. \& Comm. Mgmt., 1 (2): 139142 .

Article History : Received : 21.05.2014; Accepted : 23.06.2014

\footnotetext{
* Author for correspondence
} 